\title{
Root Deformities in Some Container-Grown Jack Pine in Southeastern Manitoba
}

\author{
L. W. Carlson and L. D. Nairn ${ }^{1}$ \\ Northern Forest Research Centre \\ Canadian Forestry Service \\ Environment Canada, Edmonton, Alberta
}

\begin{abstract}
The growth of containerized jack pine (Pinus banksiana Lamb.) seedlings three years after outplanting was still influenced by the original container configuration. Paper material from paperpots still surrounded root systems and root deformities caused by container confinement were still evident. Three types of root deformities were noted: spiraling, container compression, and kinked roots. Spiraling and container compression were most severe with seedlings grown in the BC/CFS Styro 2 and the 408 paperpot. The use of a rib-type container should eliminate spiraling. Seedling growth was directly related to the volume of the original containers, but could not be correlated with deformities.
\end{abstract}

\begin{abstract}
Résumé
Trois ans après transplantation, la croissance des semis de Pin gris (Pinus banksiana Lamb.) conteneurisés était encore influencée par la configuration du conteneur original. Les racines étaient encore entourées de particules de papier provenant des pots en papier, et elles présentaient encore des difformités causées par la contrainte du conteneur. Trois types de difformités des racines ont été alors enregistrés: l'enroulement en spirale, la compression exercée par le conteneur et la torsion. Les deux premières difformités étaient extrêmement graves chez les semis venus en styrobloc BC/ CFS 2 et en pot de papier 408. L'emploi d'un conteneur à cannelures devrait éliminer l'enroulement en spirale. La croissance des semis était directement reliée au volume des conteneurs originaux, mais ne pouvait être corrélée avec les difformités.
\end{abstract}

\section{Introduction}

Spiraling, matting, and deformation of roots of plants grown in pots have been known for a long time. In some cases being pot-bound is an advantage, especially when it induces flowering, as with African violets. However, it has been suggested that pot-bound tree seedlings have deformities that may inhibit root development and kill the seedlings (Bergman and Haggstrom 1976). The two deformities most often encountered in horticultural plantings are spiraling and kinked roots. Plants with these deformities may die, break off at the ground, or fall over, giving the tree a poor

IL. D. Nairn, N.F.R.C. suboffice, Winnipeg, Manitoba. form (Harris et al. 1967). Forest tree seedlings grown in plastic containers have similar serious deformities leading to reduced growth and vigor (Hafsia and Franclet 1966, Ben-Salem 1971). Recently the death of maritime pine (Pinus pinaster Ait.) seedlings in northern Tunisia has been attributed to strangulation by spiraling lateral roots (Franclet, pers. comm. 1976).

Containerized conifer tree seedlings for reforestation programs are becoming quite popular in western Canada. A variety of containers ranging from hard plastic to soft paper is in use. Root configuration is affected by any rigid container (Hiatt and Tinus 1974) and also by paper containers (Franclet, pers. comm. 1976).

Concern for the effect of these deformities on seedling growth and root development led us to examine a three-year-old planting of containergrown jack pine (Pinus banksiana Lamb.) at the Pineland Nursery in southeastern Manitoba.

\section{Methods}

Jack pine seedlings grown in four types of containers (Table 1) were seeded in early February 1973, cold-framed in mid-May, and hand-planted in sandy soil at the Pineland Nursery in late June 1973. Rearing methods were the same for both the Styro 2 and the paperpots (temperature $21^{\circ} \mathrm{C}$ day, $15.5^{\circ} \mathrm{C}$ night; light min. $100001 \mathrm{x}, 18-$ hour photoperiod; fertilizer applications weekly starting three weeks after germination). In June 1976, 43-47 seedlings in each type of container were lifted and the root systems examined. The data recorded and analyzed included total seedling height, root collar diameter, type of deformity, and severity of the deformity. Unfortunately, the original size of the seedlings is not available.

The deformities were designated as spiraling, container compression, and kinked roots. Spiraling severity was rated on a scale of 1 to 10 as follows: $1=$ no spiraling; $2=$ slight spiral (less than $1 / 4$ around); $3=1$ root $1 / 4$ around; $4=2+$ roots $1 / 4$ around; $5=1$ root $1 / 2$ around; $6=2+$ roots $1 / 2$ around; $7=1$ root $3 / 4$ around; $8=2+$ roots $3 / 4$ around; $9=1$ root completely spiraled; and $10=$ $2+$ roots completely spiraled. Container comprestion refers to the root systems adhering to the original container shape and was rated on a scale of 1 to 4 (none, slight, moderate, and extreme). Kinked roots were noted, but their numbers per plant were not recorded.

The data are presented as means of each treatment, and comparisons were made using a single classification ANOVA and a modified range test. A simple linear regression analysis was made for deformity factors and growth. 


\section{Results and Discussion}

There were significant differences in total seedling growth and 1976 seasonal growth between the different types of containers (Table 2). That growth was related to the original volume and diameter of the container indicates that there is still a container effect after three years. Generally, seedlings grown in larger-volume containers continued to grow better in the field. However, regression analyses indicated no correlation between growth and deformities caused by the containers.

Table 1. Dimensions of containers used for rearing jack pine seedlings

\begin{tabular}{|c|c|c|c|}
\hline Container & $\underset{\mathbf{m m}}{\text { Diameter }}$ & $\underset{\text { meight }}{\text { Hem }}$ & $\underset{\mathrm{cm}^{3}}{\text { Volume }}$ \\
\hline $\begin{array}{l}\text { BC/CFS Styro } 2 \ldots \ldots \\
213 \text { paperpot. . . . . . } \\
313 \text { paperpot. . . . . . } \\
408 \text { paperpot. . }\end{array}$ & $\begin{array}{l}25 \\
20 \\
30 \\
40\end{array}$ & $\begin{array}{r}113 \\
130 \\
130 \\
80\end{array}$ & $\begin{array}{r}38 \\
41 \\
92 \\
100\end{array}$ \\
\hline
\end{tabular}

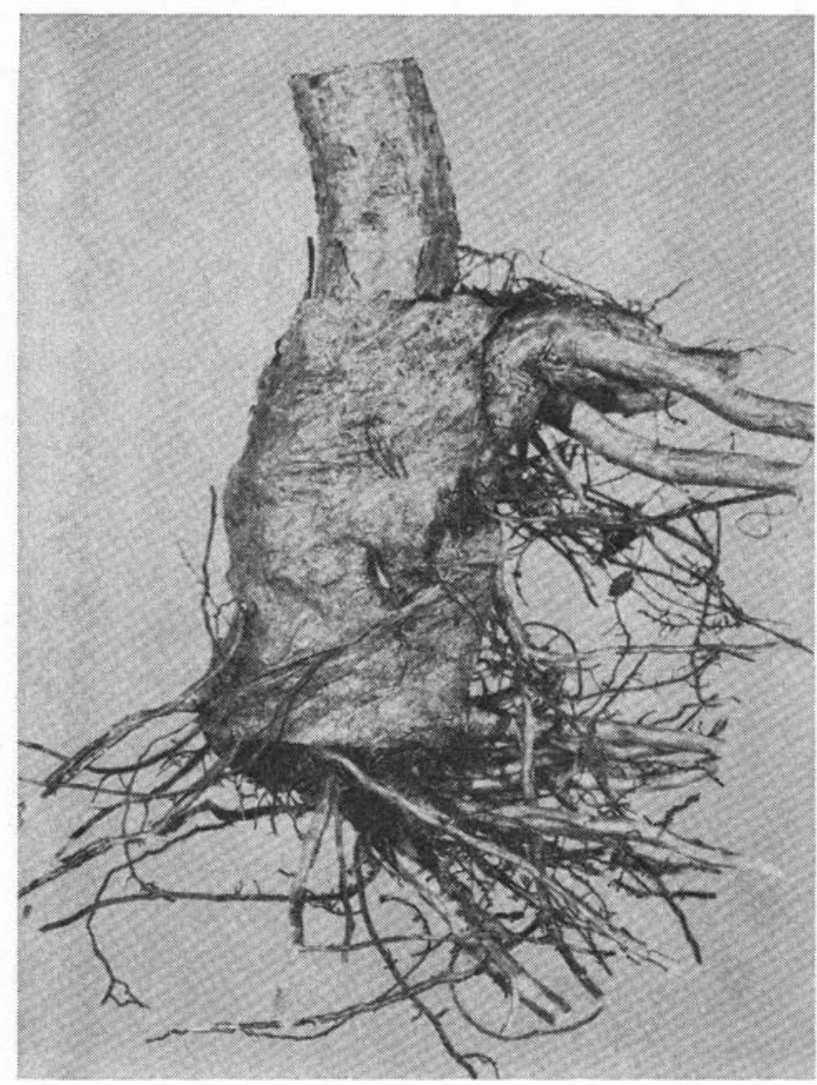

Fig. 1. The root system of a three-year-old jack pine seedling still contained in a 408 paperpot.
Root systems of most seedlings reared in paperpots were still surrounded by the paper, which had degraded only slightly (Fig. 1). Also they were still in the configuration of the original paperpot container (Fig. 2). A high percentage of all seedlings had some kinked roots (Table 2 ). The spiraling and container compression were worst in the BC/CFS Styro 2 (Fig. 3) and the 408 paperpot (Table 2), which represent both the smallest and the largest volume of container used. The intensive spiraling is not expected to be a problem in the new BC/CFS Styro 2 container because it has vertical ribs to stop spiraling and direct the root downward. However, compression is likely to continue to be a root deformity of styroblock-grown seedlings, because this type of container gave the highest compression index rating.

The onset of spiraling or container compression was not determined with these seedlings. However, recent examination of jack pine seedlings grown in containers showed that roots were conforming to the shape of the container as early as

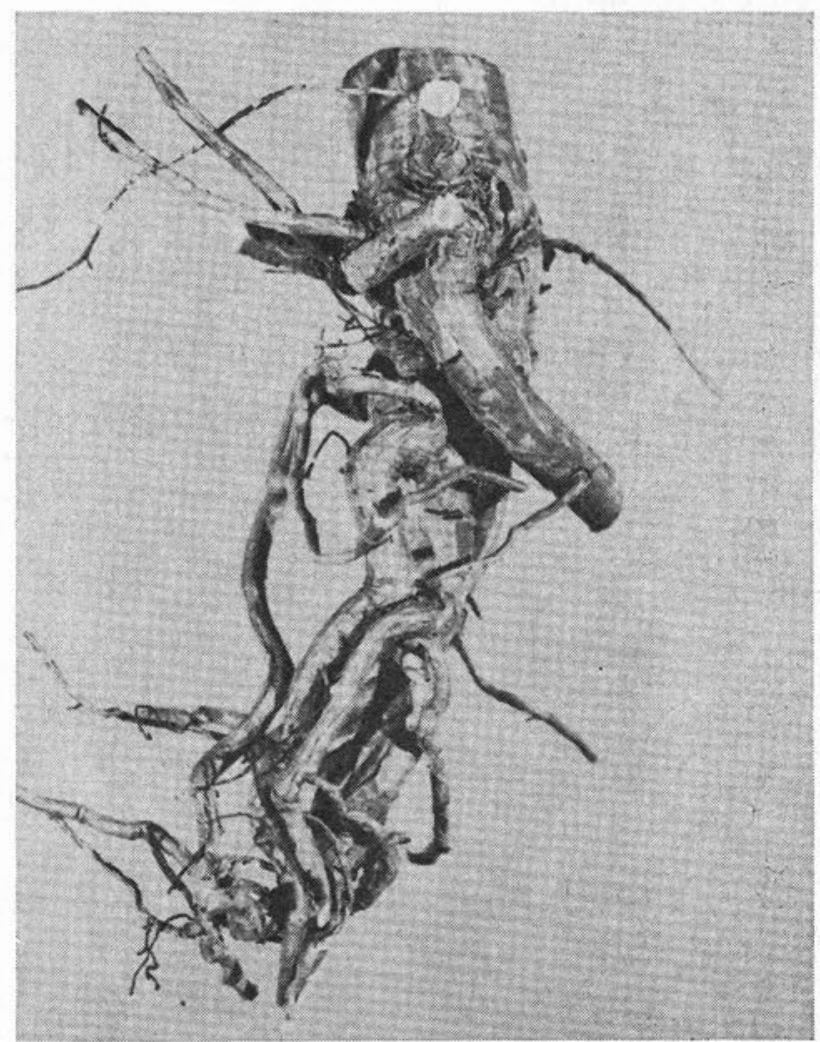

Fig. 2. The root system of a three-year-old jack pine seedling after removal of the paper material of a 408 paperpot showing container compression.

Table 2. Growth and deformity of jack pine seedlings grown in four different containers, three years after planting

\begin{tabular}{|c|c|c|c|c|c|c|}
\hline \multirow[b]{2}{*}{ Container } & \multicolumn{3}{|c|}{ Seedling } & \multicolumn{3}{|c|}{ Deformities } \\
\hline & $\begin{array}{c}\text { Total height } \\
\text { cm }\end{array}$ & $\begin{array}{l}\text { Height growth } \\
(1976), \mathrm{cm}\end{array}$ & $\begin{array}{c}\text { Root collar } \\
\text { diameter, } \mathrm{cm}\end{array}$ & $\begin{array}{l}\text { Spiral } \\
\text { index }\end{array}$ & $\begin{array}{c}\text { Compression } \\
\text { index }\end{array}$ & $\begin{array}{c}\% \text { with } \\
\text { kinked roots }\end{array}$ \\
\hline $\begin{array}{l}\text { BC/CFS Styro } 2 \ldots \ldots \ldots \ldots \ldots \\
213 \text { paperpot. } \ldots \ldots \ldots \ldots \ldots \\
313 \text { paperpot. } \ldots \ldots \ldots \ldots \ldots \ldots \\
408 \text { paperpot. } \ldots \ldots \ldots \ldots \ldots\end{array}$ & $\begin{array}{r}102.4 \mathrm{c}^{*} \\
89.4 \mathrm{~d} \\
112.2 \mathrm{~b} \\
124.4 \mathrm{a}\end{array}$ & $\begin{array}{l}47.4 \mathrm{~b} \\
41.1 \mathrm{c} \\
52.7 \mathrm{a} \\
53.5 \mathrm{a}\end{array}$ & $\begin{array}{l}1.92 \mathrm{bc} \\
1.80 \mathrm{c} \\
2.09 \mathrm{ab} \\
2.17 \mathrm{a}\end{array}$ & $\begin{array}{l}5.95 \mathrm{a} \\
4.46 \mathrm{~b} \\
4.28 \mathrm{~b} \\
5.68 \mathrm{a}\end{array}$ & $\begin{array}{l}3.64 \mathrm{a} \\
2.60 \mathrm{c} \\
2.63 \mathrm{c} \\
3.36 \mathrm{~b}\end{array}$ & $\begin{array}{l}87 \\
83 \\
98 \\
97\end{array}$ \\
\hline
\end{tabular}

*The small letters indicate multiple range groupings of treatments which do not differ significantly at the $5 \%$ level. 


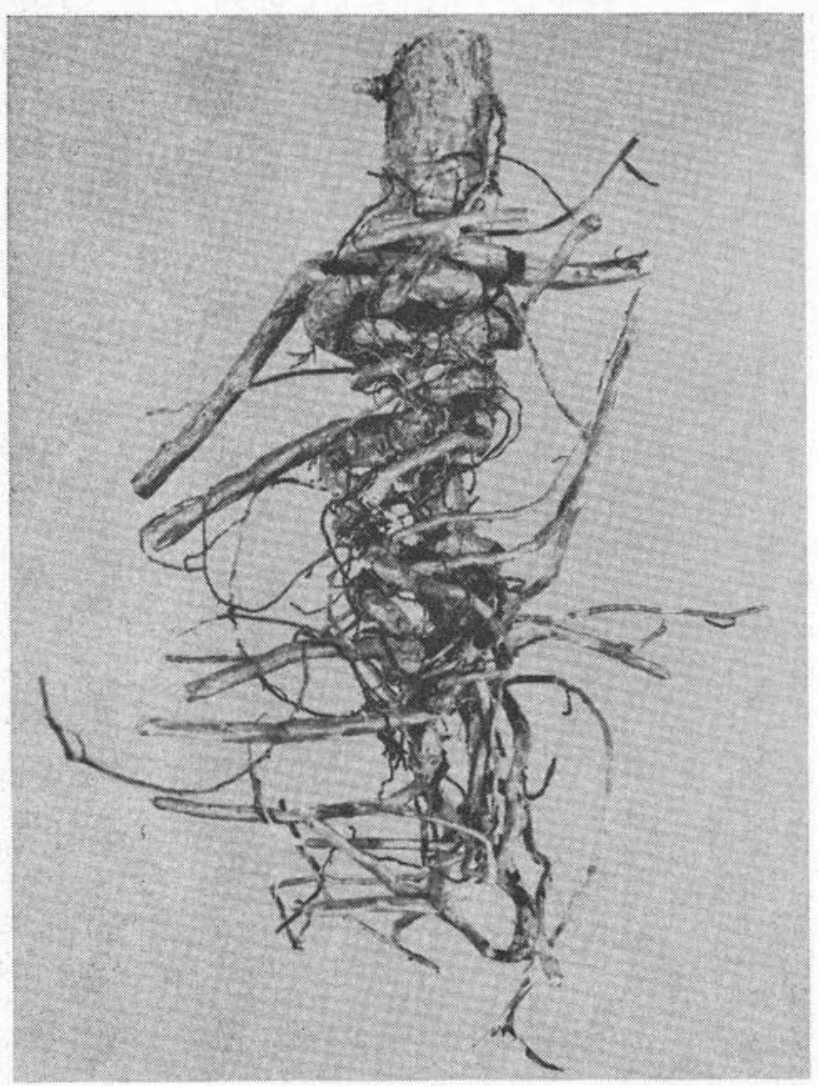

Fig. 3. The root system of a three-year-old jack pine seedling reared in the BC/CFS Styro 2, showing both spiraling and container compression.

eight weeks after seeding. Similar observations were made on maritime pine by $A$. Franclet (pers. comm).

There are many unanswered questions concerning the effect of root deformities on tree growth. The problem of mortality in maritime pine in northern Tunisia may be confounded by disease problems such as Armillaria root rot or by the effects of adverse climate. Because root systems supply water and minerals to the rest of the plant, mortality may occur quickly during climatic stresses such as extremely dry weather on dry sites; however, in areas where moisture is sufficient the seedlings may suffer no immediate stress. On moist sites the effect of the root deformities may not appear or may be delayed.

Jansson (1971) reports that there is no difference in survival and growth between eight-year-old pine seedlings with spiraled and non-spiraled root systems. However, the other workers mentioned above did find growth and survival problems. There is therefore a need to take a serious look at root deformities of young seedlings grown in containers. While the data presented here are limited to one location, they do indicate potential growth problems. In the future we plan to carry out extensive samplings of different-aged containerized seedling plantations in the prairie region of Canada to determine, if possible, the magnitude of the problem. The seriousness of the problem will dictate the type of research to follow.

Until the problem is defined there are several steps that may be taken to minimize deformities and their possible effects. Since spiraling is probably the most serious problem, rearing should be done in containers that direct the root downward such as the new BC/CFS Styro 2 or the SpencerLemaire type. The container should be removed before planting, or only rapidly degradable containers should be used. Seedlings should be reared in the container only until there is sufficient root development to hold the peat plug together. In this way container compression deformation will be kept to a minimum. Finally, containerized seedlings should be planted as soon as they have reached the prescribed size and been hardened-off. Seedlings held in the containers beyond this point will develop greater spiraling and/or compression.

\section{References}

Ben-Salem, B. 1971. Root strangulation: a neglected factor in container grown nursery stock. M.S. thesis in Forestry, Univ. of Calif., Berkeley.

Bergman, F. and B. Haggstrom. 1976. Some important facts concerning planting with rooted forest plants (Trans. by R. A. Hellenius) For. Chron. 52:266-273.

Hafsia, H. and A. Franclet. 1966. La spiralisation des racines dans l'élevage des plants en pépinière: conséquences et remèdes. Pages 1772-1773, In Proceedings, 6th World Forestry Congress, Vol. II.

Harris, R. W., D. Long and W. B. Davis. 1967. Root problems in nursery liner production. Calif. Agric. Ext. Serv. AST-244.

Hiatt, H. A. and R. W. Tinus. 1974. Container shape controls root systems configuration of ponderosa pine. Pages 194 196. In North American Containerized Forest Tree Seed ling Symposium. Denver, 1974. Great Plains Agric. Counc. Publ. No. 68.

Jansson, Karl-Ake. 1971. A pilot study on rooted pine-plants concerning root deformation. Swed. R. Coll. For. Res. Notes No. 31. 